\title{
Seasonal Changes in the North Atlantic Subtropical Gyre
}

\author{
Lothar Stramma and Gerold Siedler
}

Institut für Meereskunde, Universität Kiel, Kiel, Federal Republic of Germany

\begin{abstract}
The eastern part of the North Atlantic subtropical gyre is found in the region between the Azores and the Cape Verde Islands. A study of the gyre structure in the area east of $35^{\circ} \mathrm{W}$ between $8^{\circ} \mathrm{N}$ and $41^{\circ} \mathrm{N}$ is presented. The geostrophic flow field determined from historical temperature-salinity data sets by objective analysis indicates seasonal variations in shape but no significant changes in the magnitude of volume transports. The eastern part of the gyre has a larger east-west and smaller north-south extension in summer compared with the winter season. The center shifts by about $2^{\circ}$ latitude to the south from winter to summer. Long-term temperature time series (6.5 years) from a mooring near the Azores are consistent with these results, showing always a consistent temperature increase at the beginning of the year which is apparently due to the displacement of the northeastern part of the gyre. A comparison between the mean flow fields and fields obtained from individual zonal sections indicates large deviations north and south of the gyre but small deviations within the gyre.
\end{abstract}

\section{InTRODUCTION}

The subtropical gyre in the North Atlantic includes a recirculation regime with large transports toward the equator in the western basin [Worthington, 1976] and also smaller but significant transports in the eastern basin [Stramma, 1984a]. It is this eastern part in the Canary and Cape Verde basins which will be considered here (Figure 1). The large-scale mean structure of the gyre flow as determined in density field studies by Wunsch and Grant [1982] using inverse modeling, by olbers et al. [1985] employing the $\beta$ spiral method, and in drifter observation studies by Krauss [1986]. The data base for the eastern part of the subtropical gyre has considerable gaps compared with that for the western part. Only for certain areas does a high data density exist. These include the African coastal upwelling regions [Mittelstaedt, 1983], the area of the $\beta$ triangle near $27^{\circ} \mathrm{N}, 33^{\circ} \mathrm{W}$ [Armi and Stommel, 1983], the area of the "Kiel Warmwassersphäre Programm" between the Azores and the Canary Islands, the area along $30^{\circ} \mathrm{W}$ of the Alexander von Humboldt stations [Schemainda et al., 1976], and the area of the USSR POLYGON project near $17^{\circ} \mathrm{N}$, $33^{\circ} \mathrm{W}$ [Brekhovskikh et al., 1971]. Owing to the use of smoothed climatological data sets in the above mentioned investigations, small-scale temporal and spatial features cannot be resolved. However, when only the strongly variable upper ocean down to the lower main thermocline is being considered, data quality requirements are less stringent than in studies for the deep ocean. In the case of a strongly variable upper ocean, a broader data base with less smoothing can be used. The time-averaged southward transports east of $35^{\circ} \mathrm{W}$ for the upper $1000 \mathrm{~m}$ were determined with high spatial resolution by Stramma [1984a] from the international data set. He obtained a net transport of $11 \times 10^{6} \mathrm{~m}^{3} \mathrm{~s}^{-1}$, which is in good agreement with results from individual zonal sections presented by Saunders [1982] and Gould [1985].

We will attempt here to study the temporal variation of the gyre with the aim of verifying the existence of seasonal variations in the gyre structure. Seasonal changes in the southern part of the gyre have been known for a long time, and a recent analysis of ship drift data by Richardson and Walsh [1986] showed the North Atlantic Equatorial Countercurrent to be

Copyright 1988 by the American Geophysical Union.

Paper number $8 \mathrm{C} 0254$.

0148-0227/88/008C-0254\$05.00 strong from July through December, with a related shift of the North Equatorial Current to the north. Also, indications for seasonal variations in the northern part of the gyre, namely the Azores Current and the related subtropical front, were found by Siedler et al. [1985]. Furthermore, Stramma and Isemer [1988] noted a southward shift of the Azores Current in summer in their investigation of meridional temperature fluxes. In the present study we will use temperature-salinity data obtained from ships as well as data from moorings to determine seasonal changes in the subtropical gyre in the eastern Atlantic and to look for deviations from the annual mean.

\section{Data}

An edited data set was prepared from historical hydrographic data of the eastern North Atlantic archived at the World Oceanographic Data Center A (WODC, status 1980) for the computation of temperature $(T)$ and salinity $(S)$ curves in the eastern subtropical Atlantic [Siedler and Stramma, 1983]. Stations with dubious data apparent from spikes or systematic deviations were rejected. This data set was supplemented by conductivity-temperature-depth (CTD) profiles of a R/V Meteor cruise with two long north-south sections along $27^{\circ} \mathrm{W}$ and $33^{\circ} \mathrm{W}$ in March and April 1982 [Stramma, 1984b], CTD data from a $R / V$ Meteor cruise along about $27^{\circ} \mathrm{W}$ in April 1981 [Thiele et al., 1986], and CTDs from two of the $\beta$ triangle cruises [Armi and Stommel, 1983] made on R/V Atlantis in October 1979 and R/V Atlantis in July and August 1981. Subsets in $3^{\circ} \times 3^{\circ}$ squares were used to compute mean profiles for the periods January-March (winter), April-June (spring), July-September (summer), and October-December (fall). From all the single profiles, mean profiles were obtained for the mean position within each $3^{\circ} \times 3^{\circ}$ square. The sets of four mean profiles for spring, summer, fall, and winter were first used to compute the mean profile for the entire year. In this way, the seasons were equally weighted. In the case of missing data for one season for a $3^{\circ} \times 3^{\circ}$ square, only data from the other seasons were used.

We prefer not to exclude profiles taken within any particular square during a single cruise because it is important to have as much spatial information as possible within each square when estimating the mean profiles. However, the use of all data could lead to a bias in the interannual variability toward one year. We inspected the entire data set (Figure 2) and found that in most squares the information is spread over 


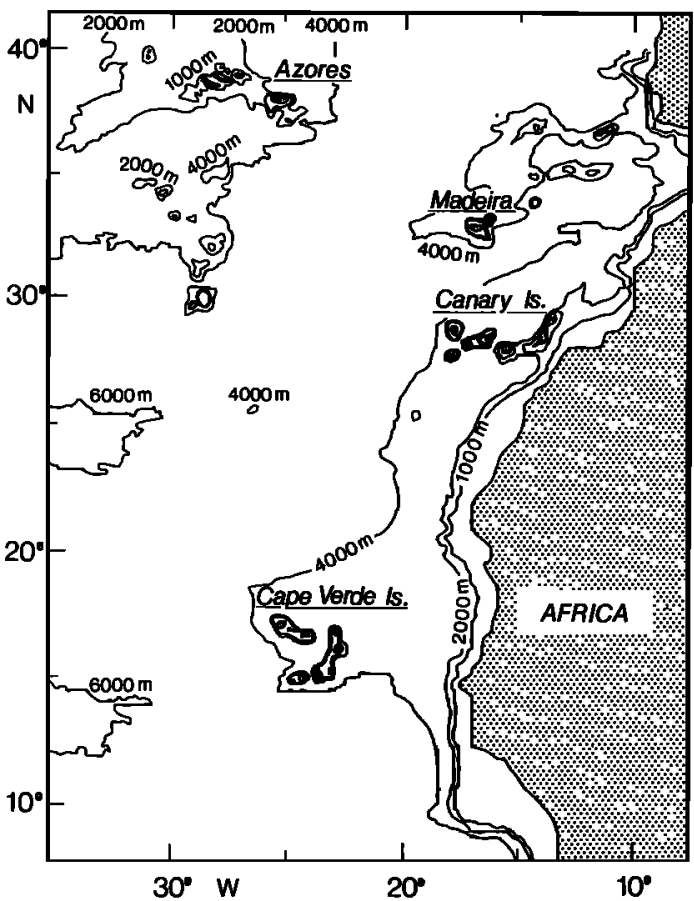

Fig. 1. Area of this study with selected depth contours.

several years, the years being different from season to season, and that in adjacent squares the data are from differing years also. This much reduces the likelihood of a large bias appearing in the interannual variability. For example, in the area $32^{\circ}$ to $35^{\circ} \mathrm{N}, 29^{\circ}$ to $32^{\circ} \mathrm{W}$, which is important for the shift of the Azores Current, we included profiles from the years 1964, 1971 , and 1971 for winter; 1965, 1969, 1969, 1971, and 1971 for spring; 1960, 1967, 1971, and 1981 for summer; and 1947, 1957, and 1979 for fall.

In addition to the hydrographic data set, data from selected moorings were used to study the seasonal variability. Mooring Kiel 276 with a nominal position at $33^{\circ} \mathrm{N}, 22^{\circ} \mathrm{W}$, at the earlier North-East Atlantic Dynamic Studies (NEADS) site 1 [Dickson et al., 1985], has been in continuous operation since April 1980. The records being considered here cover eight consecutive periods, with the mooring having been replaced seven times. We used the temperature time series of one Aanderaa current meter per mooring period in the upper ocean. The periods of the mooring records and the nominal depths of the temperature sensors are given in Table 1 . In addition to this temperature record of 6.5-year duration, the temperatures of the thermistor chain mooring Kiel 297 at $28^{\circ} \mathrm{N}, 26^{\circ} 30^{\prime} \mathrm{W}$, from October 24, 1983, to November 1, 1984, at depths between 300 $\mathrm{m}$ and $700 \mathrm{~m}$ are used. Finally, current measurements at 165 $m$ depth of mooring Kiel 303 in the Canary Current at $26^{\circ} \mathrm{N}$, $18^{\circ} \mathrm{W}$, from November 12,1984 , to October 7,1985 , are included. Details of the mooring data can be found in data reports [Müller, 1981, 1984; Müller and Zenk, 1983; Müller et al., 1987].

\section{GeOstrophic Transports}

\subsection{Transport Computations}

The method used here for determining the velocity and transport field in the upper ocean from the density distribution is the same as in an earlier approach by Stramma [1984a]. He selected a level of no motion using mean density profiles, combining information on the advection of water masses identified by oxygen and salinity maxima and minima, and a mass conservation scheme developed by Fiadeiro and Veronis [1982, 1983]. The resulting zero reference plane is found between 1500-m depth in the tropical eastern North Atlantic and 1200-m depth in the subtropics [Stramma, 1984a, Figure 6]. The reference depth was verified by Müller [1987] at the mooring location Kiel 276 (see Figure $4 a$ ) from direct current measurements over 5.5 years. Vertical shear is small at these levels below the lower boundary of the main thermocline and much larger in the upper ocean. As a result, deviations from the levels given above will not result in large changes in the transport in the upper ocean. If, for instance, the above level of no motion is replaced by a level of $2000 \mathrm{~m}$, the change in the 0 to $1000 \mathrm{~m}$ transport across a zonal section in the area of this study is less than $12 \%$. On the other hand, the total transport changes are less than $5 \%$ when noise-simulating alterations are made to the mean temperature and salinity profiles. The total error for the 0 - to 1000 -m transport, caused by the uncertainty in the reference level depth and data noise, is $15 \%$. Since it is the aim of this study to determine seasonal changes in the transport field, the question might be asked whether a seasonal change could occur in the level of no motion. The Fiadeiro and Veronis [1982, 1983] method of computing transport imbalances was used by Stramma [1984a] for triangular columns given by the mean profiles in neighboring $3^{\circ} \times 3^{\circ}$ squares. There was only one triangle where the profiles reached the seafloor for all four seasons. In that case, the results for the annual mean and for the four seasons were almost identical. This suggests that temporal changes in the level of no motion are negligibly small for the present analysis.

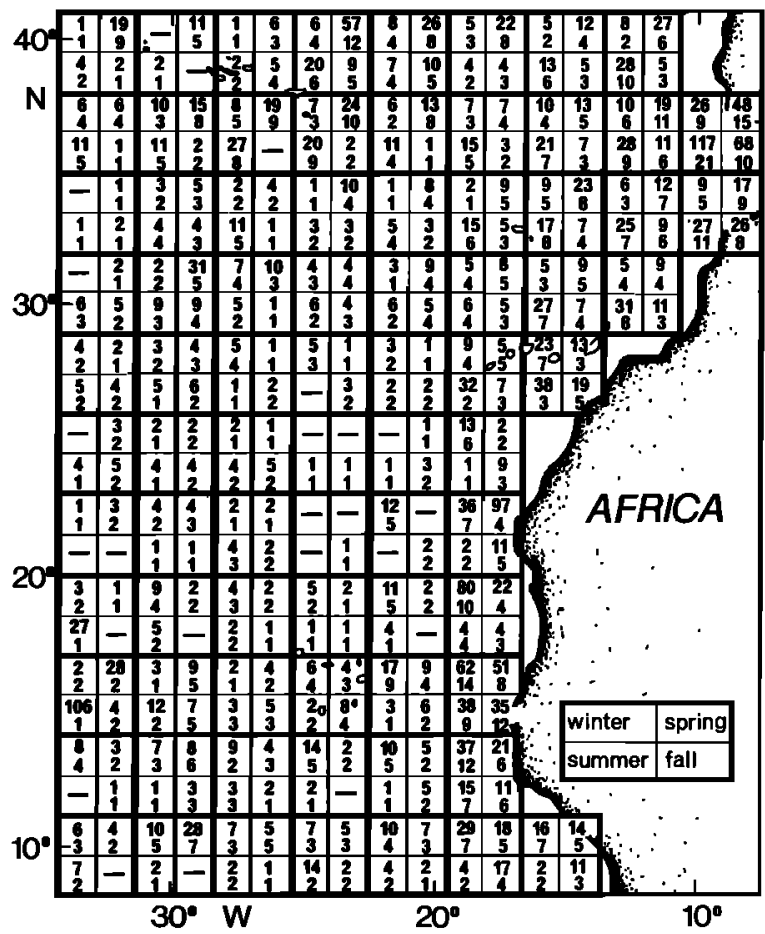

Fig. 2. Number of stations used in each $3^{\circ} \times 3^{\circ}$ square for each season (top number) and number of different years represented (bottom number) for winter (top left area), spring (top right area), summer (bottom left area) and fall (bottom right area). 


\subsection{Seasonal Variability}

The geostrophic transport integrated from the surface to $200-\mathrm{m}$ depth is shown in Figures $3 a-3 d$ for the four seasons and in Figure $4 a$ for the annual mean. The contours were determined by using an objective analysis scheme. Since the correlation scale was not known, a value of $500 \mathrm{~km}$ was chosen arbitrarily. It is about 1.5 times the typical distance between the mean profiles and is larger than the typical eddy scale. The error variance was chosen as $30 \%$ of the total variance. Tests with different correlation scales and error variances were made. The resultant flow fields show some differences in the smoothness of the flow contours and the width of the current bands, but the information on seasonal variations does not change. Barred areas in Figures 3 and 4 indicate error values larger than $0.6 \times 10^{6} \mathrm{~m}^{3} \mathrm{~s}^{-1}$. Areas of large error values reflect some $3^{\circ} \times 3^{\circ}$ squares with no profile in this season. This occurs mostly at the western and the southern boundary and in the central region between the Canary Islands and the Cape Verde Islands.

The upper ocean is expected to display the largest seasonal signal. Since the errors in transport computations increase with depth and may finally mask the seasonal signal, the analysis of seasonal transport changes was restricted to the upper $200 \mathrm{~m}$. But we also present the annual mean field for the upper $800 \mathrm{~m}$. We searched for spatial displacements of gyre-related structures which have scales comparable to the correlation scale normal to the transport direction and exceeding the correlation scale by a factor of 2 to 3 in the transport direction.

A seasonal variation of the eastern part of the subtropical gyre is recognized. To ensure that the seasonal cycle in the gyre is not due to effects of data outside of the subtropical gyre region, we repeated the computations with data between $17^{\circ} \mathrm{N}$ and $38^{\circ} \mathrm{N}$ only, the area where we see the subtropical gyre. The resulting seasonality of the subtropical gyre was the same as for the area $8^{\circ} \mathrm{N}$ to $41^{\circ} \mathrm{N}$, indicating that the information on the seasonal cycle results from the data within the smaller area. In all seasons the 0 - to $200-\mathrm{m}$ transport isolines display a separation of the Azores Current into two southward flowing current bands near $30^{\circ} \mathrm{N}$, south of Madeira (Figure 3). The boundaries of this separation area are indicated by heavy lines which facilitate tracing the displacements of the flow field in the seasonal cycle.

The gyre transport amounts to approximately $4 \times 10^{6} \mathrm{~m}^{3}$ $\mathrm{s}^{-1}$ east of $35^{\circ} \mathrm{W}$ between $0-\mathrm{m}$ and $200-\mathrm{m}$ depth. The main inflow enters south of the Azores as a relatively narrow current, the Azores Current. In all seasons the Portugal Current is weak compared with the Azores Current. The Portugal Current is directed toward the entrance of the Mediterranean Sea. The annual mean transport (Figure $4 a$ ) of the Portugal Cur-

TABLE 1. Periods of Mooring Records and Nominal Depths of Temperature Sensors

\begin{tabular}{lc}
\hline \multicolumn{1}{c}{ Period } & Depth, m \\
\hline April 1, 1980, to Oct. 17, 1980 & 379 \\
Oct. 17, 1980, to July 27, 1981 & 196 \\
July 27, 1981, to March 2, 1982 & 245 \\
March 5, 1982, to April 17, 1983 & 195 \\
April 22, 1983, to Oct. 15, 1983 & 245 \\
Oct. 20, 1983, to Oct. 25, 1984 & 330 \\
Oct. 26, 1984, to Nov. 16, 1985 & 330 \\
Nov. 17, 1985, to Nov. 1, 1986 & 302 \\
\hline
\end{tabular}

rent between $20^{\circ} \mathrm{W}$ and the Portuguese coast is $2 \times 10^{6} \mathrm{~m}^{3}$ $\mathrm{s}^{-1}$, compared with $4 \times 10^{6} \mathrm{~m}^{3} \mathrm{~s}^{-1}$ for the Azores Current.

A seasonal cycle is also evident in the position of the reversal in east-west direction at the western boundary of the area of investigation. We call it the "center," although the real center of the subtropical gyre will be located to the west of the area studied here. In winter the center is located at $29^{\circ} \mathrm{N}$ and in spring at $30^{\circ} \mathrm{N}$. The center shifts south to $27^{\circ} \mathrm{N}$ in summer and back northward to $29^{\circ} \mathrm{N}$ in fall. Related to this shift of the center in summer is a southward displacement of the northern core of the gyre, the Azores Current (Figure 3c). South of the Azores the core of the Azores Current shifts between $35^{\circ} \mathrm{N}$ in winter and $33^{\circ} \mathrm{N}$ in summer. Synoptic observations of the Azores Current have also shown a north-south shift [Käse et al., 1986]. In this case the Azores Current at $22^{\circ} \mathrm{W}$ was found in October 1984 to be $3^{\circ}$ to the south of the spring 1982 location. The data from cruises of $R / V$ Meteor and $R / V$ Oceanus in 1984 and R/V Poseidon in 1982 used by Käse et al. [1986] are not included in the mean profiles. Only the R/V Meteor data of spring 1982 are included. The synoptic observations of Käse et al. [1986], therefore, provide independent evidence of the southward shift of the Azores Current in October.

We also combined some historical ship observations near $30^{\circ} \mathrm{W}$ from different vessels and years but from the same season, which also demonstrated a southward shift of the Azores Current in summer. In reality, the Azores Current is a deep, jetlike current system [Käse et al., 1985, Siedler et al., 1985] with horizontal scales much smaller then those shown in Figure 3. The amount of geostrophic transport derived from the mean profiles will not be influenced by the smaller scales, but the position of the main horizontal gradients is less well determined. In summer the Azores Current is oriented west-east; in the other seasons the Azores Current shows a larger southward component. This west-east-oriented strong narrow band of the Azores Current is seen much more clearly in summer in the 200 - to $800-\mathrm{m}$ depth contours (not presented here).

Seasonal changes in the southern part of the gyre have been observed before. Richardson and Walsh [1986] computed near-surface currents from ship drift data south of $20^{\circ} \mathrm{N}$ and found the North Equatorial Countercurrent to be strong in the North Atlantic from July to December. The countercurrent transports equatorial water to the tropical eastern Atlantic, and related to its temporal changes is a shift of the North Equatorial Current to the north. In the tropical eastern North Atlantic, hydrographic data are sparse. Therefore the transports shown in Figure 3 for the tropics must be regarded with some caution. In summer and fall (Figures $3 c$ and $3 d$ ), equatorial water is transported to the north and contributes to the North Equatorial Current.

The salty water from the subtropics carried in the subtropical gyre is shifted to the north in the North Equatorial Current. The northward shift can be seen in Figure 5 in the salinity isohaline 35.9 on the density surface $\gamma_{\theta}=26.8 \mathrm{~kg} \mathrm{~m}^{-3}$ ( $\gamma=\rho-10^{3}, \rho$ is density, and $\theta$ is potential temperature). This density surface is 200 to $300 \mathrm{~m}$ deep in that area. The contours are taken from seasonal salinity distributions on this density surface derived with the objective analysis scheme. In summer the 35.9 isohaline is north of its winter and spring location. This isohaline has its northernmost location in the fall near $25^{\circ} \mathrm{N}$. Less salty tropical water lies to the south of the 35.9 isohaline. The northeast-to-southwest slope in salinity is 

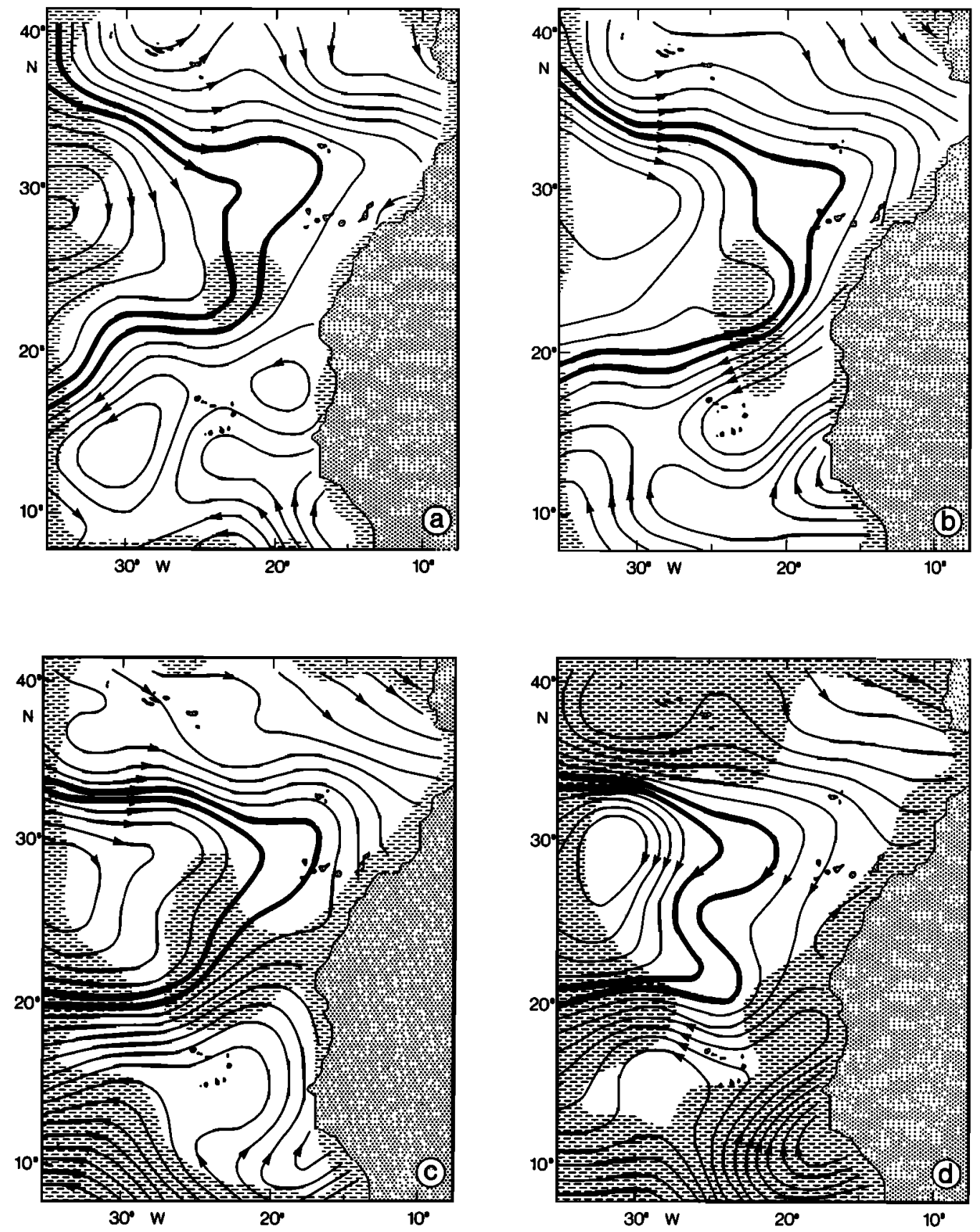

Fig. 3. Integrated volume transport ( 0 to $200 \mathrm{~m}$ ) from mean density profiles for $(a)$ January through March (winter), (b) April through June (spring), (c) July through September (summer), and (d) October through December (fall). Contour intervals represent $0.5 \times 10^{6} \mathrm{~m}^{3} \mathrm{~s}^{-1}$. The error field larger than $0.6 \times 10^{6} \mathrm{~m}^{3} \mathrm{~s}^{-1}$ is barred. Heavy lines represent limits of the separation area between the two transport bands extending from the Azores Current and are given as indicators for gyre displacments.

the well-known transition between the North and the South Atlantic Central Water [Tomczak, 1984; Emery and Meincke, 1986]. A ship drift data analysis for the eastern Atlantic Ocean (G. Jeckström, unpublished manuscript, 1983) also indicates a northward shift of the North Equatorial Current in the period July to September.

From April to September the southward transport near the African coast is larger than that from October to March, when the subtropical gyre is stronger west of the Canary Islands. In the fall (Fig. $3 d$ ) there is even a northward component south of the Canary Islands, although only in the barred area, with large error fields computed by objective analysis. However, mooring Kiel 303, deployed for 1 year in this area, also shows a northward flow in the fall of 1985 , as will be discussed in section 4. Ship drift data from the eastern Atlantic (G. Jeckström, unpublished manuscript, 1983) indicate the smallest southwestward ship drift south of the Canary Islands for the period October through December. Geostrophic computations, ship drift data, and results from a mooring all indicate a weaker Canary Current south of the Canary Islands in fall. Near the Canary Islands, some transport lines are directed toward the African coast and reappear north of $20^{\circ} \mathrm{N}$. This is 

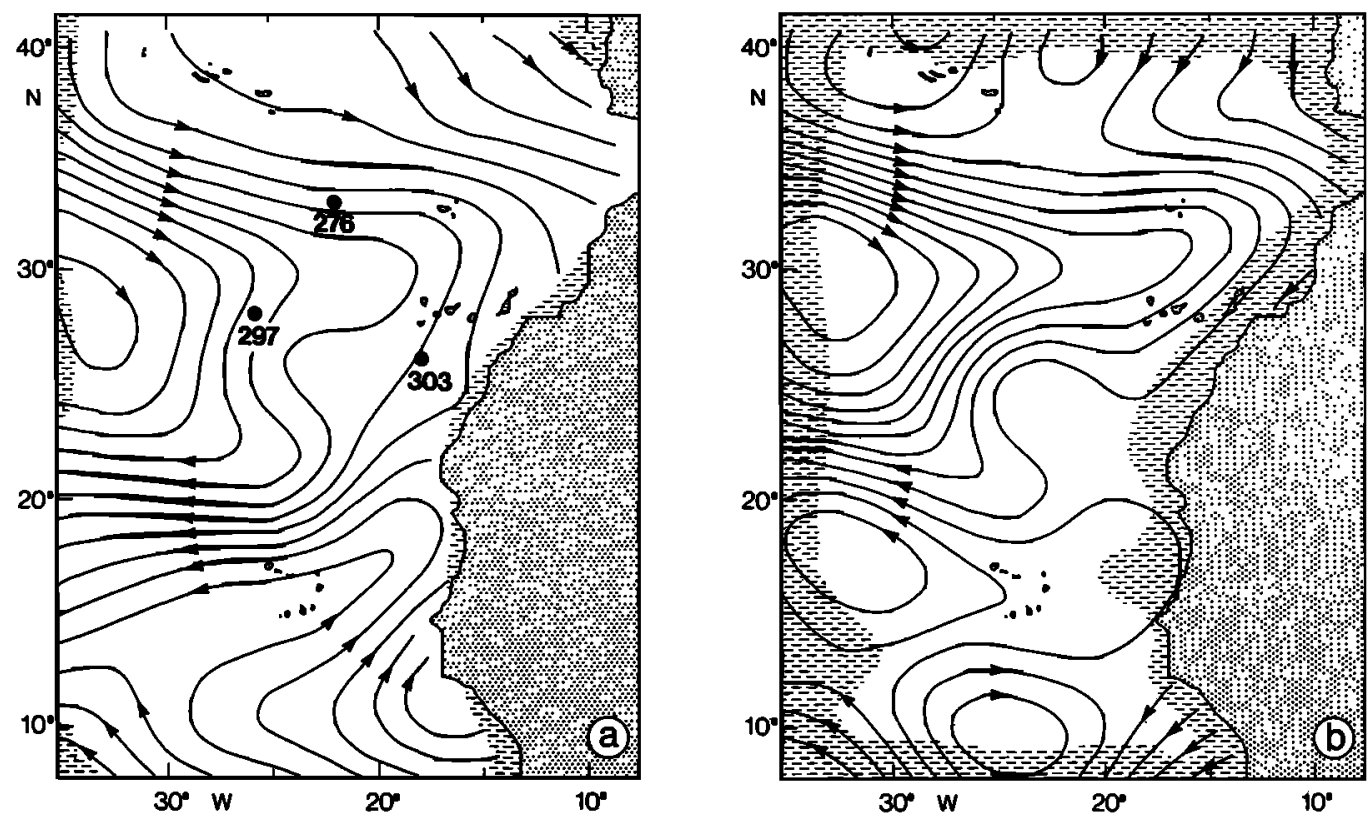

Fig. 4. Integrated volume transport as in Figure 3 but for (a) the yearly mean of 0 to $200 \mathrm{~m}$ and $(b)$ the yearly mean of 200 to $800 \mathrm{~m}$. Dots and numbers indicate the Kiel mooring locations.

suggestive of a Canary Current flowing in a narrow current band near the shelf.

In winter and spring the currents are weak southwest of Madeira. Siedler et al. [1987] observed mode water formation in this area. This Madeira Mode Water is transported to the west and south during the course of the year. The low transports, observed in winter and spring near Madeira, will promote the formation of a homogeneous water layer due to thermal convection in this area, and the stronger transport fields in summer and fall will support the advection and mixing of the mode water. The potential vorticity distribution on the R/V Meteor section east of, or along, $27^{\circ} \mathrm{W}$ in April 1981 (not presented here) shows a potential vorticity minimum at $\gamma_{\theta}$ values of about $26.5 \mathrm{~kg} \mathrm{~m}^{-3}$ between $25^{\circ} \mathrm{N}$ and $32^{\circ} \mathrm{N}$, indicating the presence of the Madeira Mode Water.

The 200- to 800 -m transport contours of the annual mean are presented in Figure $4 b$. In comparison with the 0 - to $200-\mathrm{m}$ contours (Figure $4 a$ ), it is obvious that the axis of the gyre is inclined to the north with increasing depth. This northward deflection was already observed by Armi and Stommel

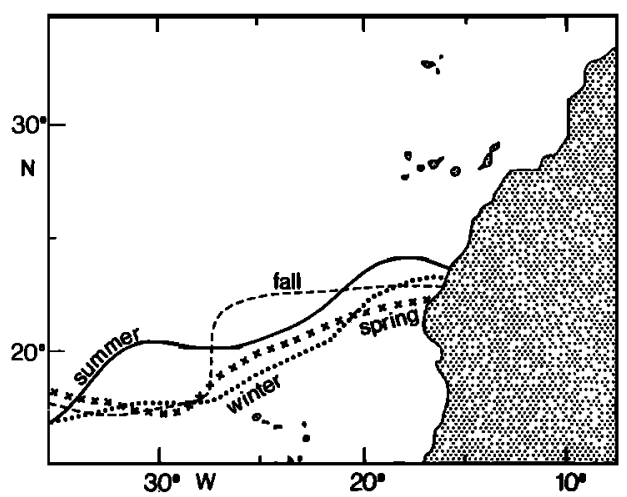

Fig. 5. Geographical location of the isohaline 35.9 on the surface of potential density $\gamma_{\theta}=26.8 \mathrm{~kg} \mathrm{~m}^{-3}$ (about 200 to $300 \mathrm{~m}$ deep) shown for the four seasons as defined in the legend of Figure 3.
[1983] in the $\beta$ triangle data. In the $200-$ to $800-\mathrm{m}$ layer, therefore, the subtropical gyre does not extend as far south as it does in the top $200 \mathrm{~m}$. The seasonal cycle of the center of the gyre, as well as the southward shift of the Azores Current, is apparent in the seasonal flow contours of the $200-$ to $800-\mathrm{m}$ depth. Since there is no new information on the seasonal changes in the results for the 200- to 800 -m layer and the error fields increase considerably, the figures for this layer are not presented here.

In summary, we observe a part of the subtropical gyre in the eastern North Atlantic with larger east-west extension and smaller north-south extension in summer than in winter. In the North Equatorial Current the errors of the geostrophic flow fields are too large to prove the north-south shift, but it is seen in the salinity distribution (Figure 5). A schematic presentation of the shape of the subtropical gyre in summer and winter in the top $200 \mathrm{~m}$ of the eastern North Atlantic is given in Figure 6. The center is also indicated in this figure. The magnitude of the transport in the upper $200 \mathrm{~m}$ of the ocean does not change significantly and is approximately $4 \times 10^{6} \mathrm{~m}^{3}$ $\mathrm{s}^{-1}$ in all seasons, but the structure of the gyre changes seasonally.

\subsection{Deviations From the Annual Mean}

The historical oceanographic data base is too small to investigate interannual variability from mean profiles. We can, however, use some single sections to investigate deviations from the seasonal mean. In Table 2 we present a comparison between the geostrophic transport from International Geophysical Year (IGY) sections east of $35^{\circ} \mathrm{W}$ and the seasonal mean transports. The Crawford section in October 1959 at $40^{\circ} 15^{\prime} \mathrm{N}$ shows a southward transport of $0.5 \times 10^{6} \mathrm{~m}^{3} \mathrm{~s}^{-1}$ east of $35^{\circ} \mathrm{W}$ including the coastal area of the Portugal Current, less than the $1.4 \times 10^{6} \mathrm{~m}^{3} \mathrm{~s}^{-1}$ for the mean fall value in the upper $200 \mathrm{~m}$. The higher transport indicated in Figure $4 a$ is introduced by the objective analysis scheme, close to the strong Azores Current at the northern boundary of the select- 


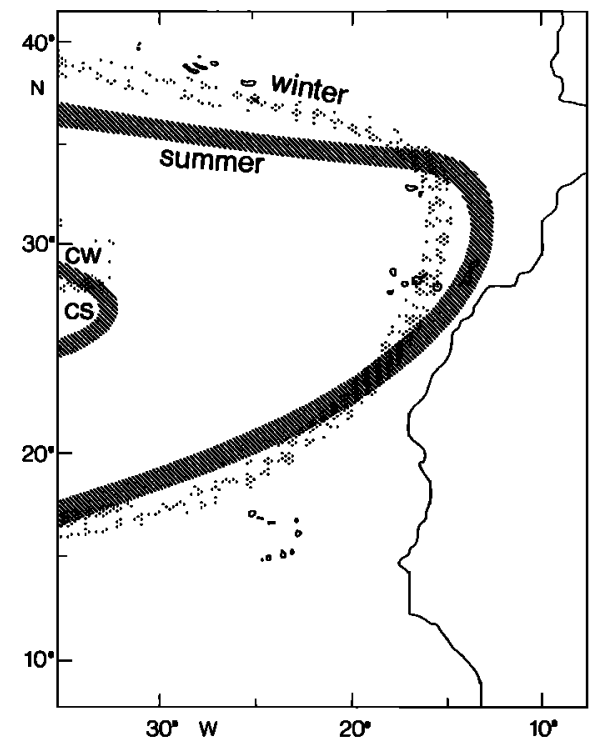

Fig. 6. Schematic presentation of the subtropical gyre in summer and winter in the top $200 \mathrm{~m}$ of the ocean. The reversal of the flow direction on the western boundary is shown for summer (CS) and winter $(\mathrm{CW})$

ed area. The Chain section along $36^{\circ} 15^{\prime} \mathrm{N}$ in May 1959 presents a southward transport of $3.5 \times 10^{6} \mathrm{~m}^{3} \mathrm{~s}^{-1}$, and our spring mean transport at this latitude is $2.7 \times 10^{6} \mathrm{~m}^{3} \mathrm{~s}^{-1}$ to the south. The difference might be variability in the current strength or the influence of the shift of the Azores Current. The three sections at $32^{\circ} 15^{\prime} \mathrm{N}, 28^{\circ} 15^{\prime} \mathrm{N}$, and $24^{\circ} 30^{\prime} \mathrm{N}$ give transport values which are within $0.5 \times 10^{6} \mathrm{~m}^{3} \mathrm{~s}^{-1}$ of the seasonal mean for the respective season. This indicates a subtropical gyre with stable transport values and weak variability. The Crawford section in November 1957 at $16^{\circ} 15^{\prime} \mathrm{N}$ shows a northward transport of $1.8 \times 10^{6} \mathrm{~m}^{3} \mathrm{~s}^{-1}$. The data base for the seasonal mean at this latitude is very limited and the mean fail transport of $1.0 \times 10^{6} \mathrm{~m}^{3} \mathrm{~s}^{-1}$ to the north might be influenced considerably by the Crawford section. The data from the IGY sections are included in the mean profiles, and the seasonal mean and IGY transports are therefore not independent of each other. On the other hand, the data base in the subtropical area is still large enough to distinguish transport deviations of single sections from the mean transports.

In the subtropical gyre, the IGY sections indicate only small deviations from the annual mean, while at the latitude of the

TABLE 2. Meridional Geostrophic Transports in Sverdrups From IGY Sections and From the Related Seasonal Means for 0 to $200 \mathrm{~m}$ East of $35^{\circ} \mathrm{W}$

\begin{tabular}{|c|c|c|c|}
\hline Ship & Latitude & $\begin{array}{l}\text { Individual } \\
\text { Section } \\
\text { Transport }\end{array}$ & $\begin{array}{c}\text { Seasonal } \\
\text { Mean } \\
\text { Transport }\end{array}$ \\
\hline Crawford (October 1959) & $40^{\circ} 15^{\prime} \mathrm{N}$ & -0.5 & -1.4 \\
\hline Chain (May 1959) & $36^{\circ} 15^{\prime} \mathrm{N}$ & -3.5 & -2.7 \\
\hline $\begin{array}{l}\text { Discovery (December } \\
\text { 1957) }\end{array}$ & $32^{\circ} 15^{\prime} \mathrm{N}$ & -3.8 & -4.0 \\
\hline Atlantis (February 1959) & $28^{\circ} 15^{\prime} \mathrm{N}$ & -4.4 & -4.2 \\
\hline $\begin{array}{l}\text { Discovery (October } \\
\text { 1957) }\end{array}$ & $24^{\circ} 30^{\prime} \mathrm{N}$ & -4.2 & -3.7 \\
\hline $\begin{array}{l}\text { Crawford (November } \\
\text { 1957) }\end{array}$ & $16^{\circ} 15^{\prime} \mathrm{N}$ & +1.8 & +1.0 \\
\hline
\end{tabular}

Positive sign represents northward transport $\left(1 \mathrm{~Sv}=10^{6} \mathrm{~m}^{3} \mathrm{~s}^{-1}\right)$.
Azores and in the tropics at $16^{\circ} 15^{\prime} \mathrm{N}$, variability is large. It is unclear at this point whether the transport deviations in individual sections are typical and suggestive of interannual variations of similar magnitude. At least there appears to be a consistent spatial pattern. Another indication in this direction is given by the results of Roemmich and Wunsch [1985]. After a repetition of the sections at $24^{\circ} 30^{\prime} \mathrm{N}$ and $36^{\circ} 15^{\prime} \mathrm{N}$ in mid1981 , they found that the repeated sections have similar features in their large-scale velocity and similar zonally averaged meridional transports, supporting our findings of low variability in the subtropical gyre.

\section{Direct Measurements}

The mooring Kiel 276 with the nominal position at $33^{\circ} \mathrm{N}$, $22^{\circ} \mathrm{W}$, is located in the eastern extension of the Azores Current. Since this current was found in historical hydrographic data to shift with the seasonal cycle, we searched for a possible seasonal cycle in the mooring data time series. The long record of 6.5 years is advantageous, but the mooring's location in the eastern extension of the Azores Current is unfortunate because the total transport is weaker in this region compared with the transport south of the Azores. The currents in the upper ocean are governed by strong-current events on the scale of 1-3 months [Siedler et al., 1985] which mask the small signal of the seasonal cycle. Using a 180-day mean every 90 days, Müller [1987] found a northward velocity component in the winters and a southward component in the summers of 1980 and 1981. However, the overall results on seasonal current variations are inconclusive.

Temperature records may be better suited for a study of variations caused by seasonal changes in the position of the water mass boundary. A displacement of the boundary in the direction of the horizontal temperature gradient will generate a strong temperature signal at a fixed position in the boundary region but may well cause only small variations in the baroclinic currents which are predominantly normal to the horizontal temperature gradient and constant in the case of a constant density gradient. As a result, the signal-to-noise ratio may be better in the case of seasonal temperature variations.

We therefore attempted to obtain a temperature time series at a fixed depth, using appropriate vertical interpolation and smoothing in time. For this purpose the annual mean temperature profile from historical data for the $3^{\circ} \times 3^{\circ}$ square including the mooring site was approximated by a second-order polynomial in the upper $500 \mathrm{~m}$. The depths of the temperature sensors on the mooring were first corrected for vertical displacements due to mooring inclination by current drag, using pressure sensor records. The temperatures at 200-m depth were then obtained by applying the above polynomial for the interpolation in the vertical. No corrections were made for the different seasonal temperature amplitudes at different depths. They are diflicult to estimate. For this reason the amplitude at the end of the record is lower because the actual temperature sensor was at a greater depth during this time. During the first period of April 1, 1980, to October 17, 1980, the pressure sensor at 379-m depth had lailed, and the pressure changes at $673 \mathrm{~m}$ had to be used. This sensor showed an amplitude similar to that of another pressure sensor at a depth of $24 \mathrm{~m}$ on the same mooring. During the last period, from November 1985 to November 1986, the only pressure sensor in the mooring failed. From the current measurements at different depths it is obvious in this case that no strong barotropic flow had reached the mooring during this period and no large incli- 


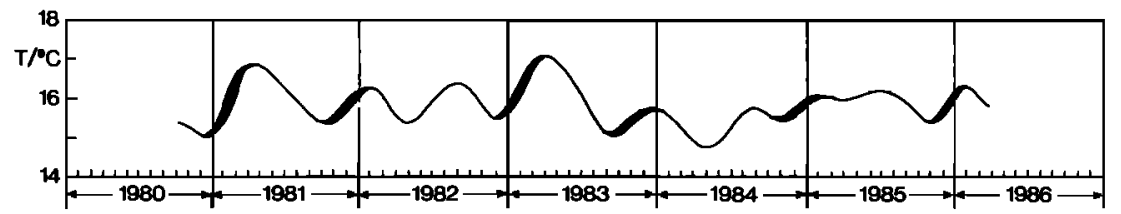

Fig. 7. Temperature time series at $33^{\circ} \mathrm{N}, 22^{\circ} \mathrm{W}$. The curve was interpolated to $200-\mathrm{m}$ depth and low-pass filtered over

179 days. The temperature increase at the turn of the year is indicated by the heavy lines.

nation of the mooring due to current drag was probable. Therefore the depth correction was only made for the difference between the nominal depth (302 m) and $200 \mathrm{~m}$.

Furthermore, the temperature time series at 200 -m depth was linearly interpolated in time for the gaps between mooring recovery and launching and finally low-pass filtered over 179 days. With this filter we loose 6 months of data at the beginning and the end of the time series, but we also delete the short-term signals of mesoscale eddies or other events.

The resulting temperature time series is given in Figure 7. The temperature at $200 \mathrm{~m}$ always increases in January except for January 1984, when the maximum winter temperature was reached earlier (in December 1983). For the period shown here there is always a temperature increase in winter which is apparently related to the northward shift of the Azores Current in winter known from the geostrophic currents obtained from historical data (Figure 3). This temperature increase in winter is in contrast to the normal seasonal temperature cycle near the surface at northern latitudes. When the subtropical gyre in the Azores Current region shifts to the north, salty and warm water advances to the north. Some of the Aanderaa current meters were also equipped with conductivity cells. The resultant salinity records do indeed display saltier water in winter, but there is no complete record of salinity for the upper ocean over the 6.5-year mooring period. The accuracy of the salinity measurements on the moorings is marginal, and therefore no figure is presented here. In 1982, 1984, and 1985 in late summer a second temperature maximum is seen at the mooring location. We can only speculate that this may be caused by a meandering of the Azores Current on shorter than annual time scales.

For a comparison with this time series the temperature data from the thermistor chain mooring Kiel 297 at $28^{\circ} \mathrm{N}, 26^{\circ} 30^{\prime} \mathrm{W}$

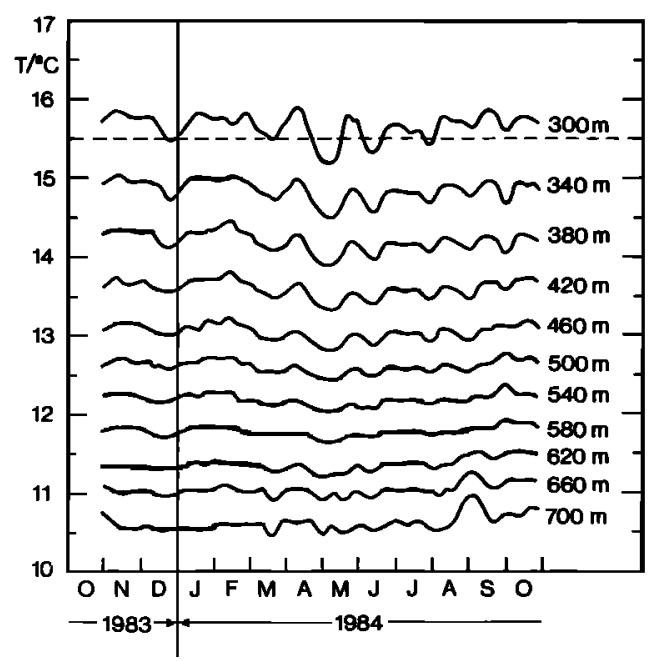

Fig. 8. Temperature time series at $28^{\circ} \mathrm{N}, 26^{\circ} 30^{\prime} \mathrm{W}$, between $300-\mathrm{m}$ and $700-\mathrm{m}$ depth from October 1983 to October 1984. The data are smoothed with a 10 -day running mean. (see Figure 4), are presented in Figure 8. The temperature time series are given between 300 and $700 \mathrm{~m}$, in intervals of $40 \mathrm{~m}$. The curves were smoothed with a 10-day running mean. The location of this mooring is close to the center of the subtropical gyre, and the temperature signal is expected to be weak. The temperature curves are much smoother than at the mooring in the Azores Current, but the curves in Figure 8 also show some tendency to higher temperatures in January and February 1984.

Finally, current measurements from mooring Kiel 303 at $165 \mathrm{~m}$ depth on $26^{\circ} \mathrm{N}, 18^{\circ} \mathrm{W}$ (see Figure 4) from November 1984 to October 1985 are shown in Figure 9. This mooring is located in the Canary Current south of the Canary Islands. The seasonal geostrophic computations showed a weakening of the Canary Current in winter and spring. This 1-year current record shows a northward flow in November and in the beginning of December 1984 and then again at the end of September and the beginning of October 1985. The strongest southward flow is observed in June and July of 1985. From January to May the current is weak and variable, with northwestward flow at the end of April and the beginning of May 1985. For this 1-year period in Figure 9 the measured current velocity at $165-\mathrm{m}$ depth is consistent with the basic features of seasonal variations found in the geostrophic computations based on historical data.

\section{Conclusion}

We can state that the seasonal variations in the structure of the eastern part of the North Atlantic subtropical gyre, as determined from historical density data, is consistent with results from long-term observations with moored temperature sensors, with seasonal changes of the salinity at the central water boundary off West Africa, and with ship drift data results. It remains to be demonstrated by numerical modeling whether the observed changes are caused solely by the large seasonal wind stress variation [Hellerman and Rosenstein, 1983; Isemer and Hasse, 1987] in the northern and southern part of the area investigated here. The data base is not sufficiently complete at this time to determine interannual variations in the structure of the subtropical gyre.

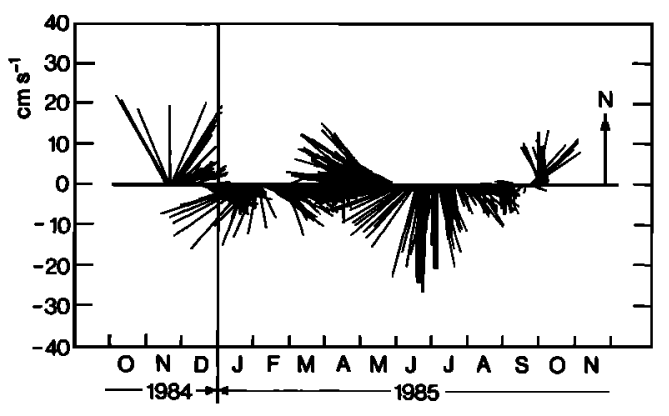

Fig. 9. Current vector time series at $26^{\circ} \mathrm{N}, 18^{\circ} \mathrm{W}$, at $165-\mathrm{m}$ depth from November 1984 to October 1985. 
Acknowledgments. We would like to acknowledge the assistance of the data processing staff of the Marine Physics Group at the Institut fïr Meereskunde, Kiel. We want to thank $L$. Armi for providing the tapes of two of the beta triangle cruises, T. J. Müller for assistance in the mooring data processing, and $\mathrm{E}$. Tidmarsh for helpful comments on the text. This work was supported by the Deutsche Forschungsgemeinschaft grant SFB 133.

\section{REFERENCES}

Armi, L., and $H$. Stommel, Four views of a portion of the North Atlantic subtropical gyre, J. Phys. Oceanogr., 13, 828-857, 1983.

Brekhovskikh, L. M., K. N. Fedorov, L. M. Fomin, M. N. Koshlyakov, and A. D. Yampolsky, Large scale multi-buoy experiment in the tropical Atlantic, Deep Sea Res., 18, 1189-1206, 1971.

Dickson, R. R., W. J. Gould, T. J. Müller, and C. Maillard, Estimates of the mean circulation in the deep ( $>2000 \mathrm{~m}$ ) layer of the eastern North Atlantic, Prog. Oceanogr., 14, 103-127, 1985.

Emery, W. J., and J. Meincke, Global water masses: Summary and review, Oceanol. Acta, 9, 383-391, 1986.

Fiadeiro, M. E., and G. Veronis, On the determination of absolute velocities in the ocean, J. Mar. Res., 40, suppl., 159-182, 1982.

Fiadeiro, M. E., and G. Veronis, Circulation and heat flux in the Bermuda triangle, J. Phys. Oceanogr., 13, 1158-1169, 1983.

Gould, W. J., Physical oceanography of the Azores front, Prog. Oceanogr., 14, 167-190, 1985.

Hellerman, S., and M. Rosenstein, Normal monthly wind stress over the world ocean with error estimates, J. Phys. Oceanogr., 13, 1093$1104,1983$.

Isemer, H.-J., and L. Hasse, The Bunker Climate Atlas of the North Atlantic Ocean, vol. 2, Air-Sea Interactions, 252 pp., SpringerVerlag, New York, 1987.

Käse, R. H., W. Zenk, T. B. Sanford, and W. Hiller, Currents, fronts, and eddy fluxes in the Canary Basin, Prog. Oceanogr. 14, 231-257, 1985.

Käse, R. H., J. F. Price, P. L. Richardson, and W. Zenk, A quasisynoptic survey of the thermocline circulation and water mass distribution within the Canary Basin, J. Geophys. Res., 91, 9739-9748, 1986.

Krauss, W., The North Atlantic Current, J. Geophys. Res., 91(C4), 5061-5074, 1986.

Mittelstaedt, E., The upwelling area off northwest Africa-A description of phenomena related to coastal upwelling, Prog. Oceanogr., 12, 307-331, 1983.

Müller, T. J., Current and temperature measurements in the northeast Atlantic during NEADS, Ber. Inst. Meereskund., Christian Albrechts Univ. Kiel, 90,100 pp., 1981.

Müller, T. J., Eulerian current measurements from the north east Atlantic, March 1982-October 1983-A data report, Ber. Inst. Meereskd. Christian Albrechts Univ. Kiel, 127, 99 pp., 1984.

Müller, T. J., Analyse niederfrequenter Strömungsschwankungen im Nordostatlantik, Doctoral dissertation, 134 pp., Kiel Univ., Kiel, Federal Republic of Germany, 1987.

Müller, T. J., and W. Zenk, Some Eulerian current measurements and XBT-sections from the north east Atlantic October 1980-March
1982-A data report, Ber. Inst. Meereskd. Christian Albrechts Univ. Kiel, II4, 145 pp., 1983.

Müller, T. J., M. Finke, W. Dasch, and R.-R. Wittstock, Hydrographic and current measurements in the north-east Atlantic Ocean, Ber. Inst. Meereskd. Christian Albrechts Univ. Kiel, 166, 106 pp., 1987.

Olbers, D. J., M. Wenzel, and J. Willebrand, The inference of North Atlantic circulation patterns from climatological hydrographic data, Rev. Geophys., 23, 313-356, 1985.

Richardson, P. L., and D. Walsh, Mapping climatological seasonal variations of surface currents in the tropical Atlantic using ship drifts, J. Geophys. Res., 9J, 10,537-10,550, 1986.

Roemmich, D., and C. Wunsch, Two transatlantic sections: Meridional circulation and heat flux in the subtropical North Atlantic Ocean, Deep Sea Res., 32, 619-664, 1985.

Saunders, P. M., Circulation in the eastern North Atlantic, J. Mar. Res., 40, suppl., 641-657, 1982.

Schemainda, R., W. Kaiser, D. Nehring, and S. Schulz, Ozeanologische Untersuchungen im tropischen Nordatlantik auf $30^{\circ} \mathrm{W}$ zwischen $2^{\circ} \mathrm{N}-15^{\circ} \mathrm{N}$, Geod. Geophys. Veroeff., Reihe IV, Heft 15, 52 pp., 1976.

Siedler, G., and L. Stramma, The applicability of the $T / S$ method to geopotential anomaly computations in the northeast Atlantic, Oceanol. Acta, 6, 167-172, 1983.

Siedler, G., W. Zenk, and W. J. Emery, Strong current events related to a subtropical front in the northeast Atlantic, J. Phys. Oceanogr., 15, 885-897, 1985.

Siedler, G., A. Kuhl, and W. Zenk, The Madeira Mode Water, J. Phys. Oceanogr., 17, 1561-1570, 1987.

Stramma, L., Geostrophic transport in the warm water sphere of the eastern subtropical North Atlantic, J. Mar. Res., 42, 537-558, $1984 a$.

Stramma, L., Potential vorticity and volume transport in the eastern North Atlantic from two long CTD sections, Dtsch Hydrogr. Z., 37, 147-155, $1984 b$.

Stramma, L., and H.-J. Isemer, Seasonal variability of meridional temperature fluxes in the eastern North Atlantic Ocean, J. Mar. Res., 46, 281-289, 1988.

Thiele, G., W. Roether, P. Schlosser, R. Kuntz, G. Siedler, and L. Stramma, Baroclinic flow and transient-tracer fields in the CanaryCape-Verde Basin, J. Phys. Oceanogr., 16, 814-826, 1986.

Tomczak, M., Ausbreitung und Vermischung der Zentralwassermassen in den Tropengebieten der Ozeane, 1, Atlantischer Ozean, Oceanol. Acta, 7, 145-158, 1984.

Worthington, L. V., On the North Atlantic circulation, Johns Hopkins Stud. Oceanogr. 6, 110 pp., 1976.

Wunsch, C., and B. Grant, Towards the general circulation of the North Atlantic Ocean, Prog. Oceanogr., 11, 1-59, 1982.

G. Siedler and L. Stramma, Institut für Meereskunde, Universität Kiel, Düsternbrooker Weg 20, D-2300 Kiel 1, Federal Republic of Germany.

(Received December 18, 1987; accepted January 26, 1988.) 